\title{
Vegetation and wildfire controls on sediment yield in bedrock landscapes
}

\author{
Roman A. DiBiase ${ }^{1}$ and Michael P. Lamb ${ }^{1}$ \\ Received 3 January 2013; revised 16 February 2013; accepted 19 February 2013; published 27 March 2013.
}

[1] Steep, rocky landscapes commonly exhibit high sediment yields and are especially sensitive to climate, tectonics, and wildfire. Predicting landscape response to these perturbations demands a quantitative understanding of erosion processes. However, existing models for hillslope sediment production and transport do not apply to landscapes with patchy soil and slopes that exceed the angle for sediment stability. Here we present field measurements in southern California, USA, which indicate that sediment storage on steep slopes is enabled by vegetation that traps sediment upslope. We find that the storage capacity of unburned vegetation dams follows a geometric scaling model with a cubic dependence on effective plant width and an inverse dependence on local slope. Measured sediment volumes behind burned vegetation dams indicate a loss of at least $75 \%$ relative to unburned dams, and when expanded to the catchment scale, our measurements match records of postfire sediment yield from nearby retention basins. Contrary to existing models, our observations indicate that wildfire-induced sediment yield is driven by transient storage and release of sediment by vegetation dams, rather than increased bedrock-to-soil conversion rates. Without a feedback between soil production and wildfire, fire may play little role in long-term landscape evolution, and increasing fire frequency in response to climate change may not result in heightened sedimentation hazards due to supply limitations. Citation: DiBiase, R. A., and M. P. Lamb (2013), Vegetation and wildfire controls on sediment yield in bedrock landscapes, Geophys. Res. Lett., 40, 1093-1097, doi:10.1002/grl.50277.

\section{Introduction}

[2] Quantifying the processes and rates of soil production, storage, and transport is essential to understanding hillslope response to tectonic, climatic, and anthropogenic forcing [Dietrich et al., 2003; Tucker and Hancock, 2010]. While considerable progress has been made in our understanding of sediment transport in soil-mantled landscapes [e.g., Roering, 2008], much less is known about steep, bedrock hillslopes that lack a continuous soil cover and where transport events are highly stochastic and involve long travel distances. Sediment transport processes on steep hillslopes are dominated by episodic slope failure, ranging from dry ravel to block fall to deep-seated bedrock landslides [Selby, 1993]. Here we focus on the process of dry ravel-the

\footnotetext{
${ }^{1}$ Division of Geological and Planetary Sciences, California Institute of Technology, Pasadena, California, USA.

Corresponding author: R. A. DiBiase, Division of Geological and Planetary Sciences, California Institute of Technology, 1200 E. California Blvd., Pasadena, CA 91125, USA. (rdibiase@caltech.edu)

(C)2013. American Geophysical Union. All Rights Reserved. 0094-8276/13/10.1002/grl.50277
}

rolling, bouncing, and sliding of particles in response to disturbance that is common in steep, semi-arid landscapes. Gabet [2003] and Gabet and Mendoza [2012] used field and laboratory measurements to show that both sediment transport distance and volumetric flux from dry ravel increase rapidly as slopes approach the angle of repose for loose sediment (typically $30-40^{\circ}$ ). These results are analogous to similar studies of granular creep processes [Roering et al., 2001; Tucker and Bradley, 2010] and predict that sediment flux becomes infinite at slopes that exceed a critical slope, implying that the sediment flux there must be limited by the conversion of rock to sediment, and hillslopes should be devoid of sediment cover. However, bare bedrock slopes are rare even where local hillslope angles exceed this critical slope [DiBiase et al., 2012], which can be explained in part by the local stability provided by vegetation.

[3] Vegetation dams are important because, when incinerated during wildfire, they can rapidly release large volumes of sediment to river channels [Florsheim et al., 1991; Lamb et al., 2011], which in turn can fuel catastrophic hyperconcentrated floods and debris flows [Eaton, 1935; Wells, 1987; Cannon et al., 2010a; Kean et al., 2011]. Sediment storage by vegetation and its release following wildfire have not been quantified on bedrock hillslopes, leaving many first-order questions unanswered: Why does sediment yield increase following fire? Will climate change and increased fire frequency result in more sediment hazards? Do fires affect landscape evolution? In this paper, we present the first measurements, to our knowledge, of sediment accumulation behind vegetation dams on steep bedrock hillslopes and explore the first-order control of dam width on the storage capacity of vegetation dams. Additionally, we use previous field estimates of vegetation stem density and light detection and ranging (LiDAR) topography to make predictions of catchment-scale sediment storage in the front range of the San Gabriel Mountains in California, and use nearby rates of soil production to explore the timescales of hillslope response to fire.

\section{Field Setting}

[4] The San Gabriel Mountains (SGM) are an ideal testing ground for studying the interplay of sediment transport, vegetation, and wildfire on steep slopes. They are composed primarily of highly fractured granitic and metamorphic rock that despite its weakness sustains catchment-mean hillslope angles of up to $40^{\circ}$ due to rapid uplift $(0.5-1 \mathrm{~mm} / \mathrm{yr})$ along the Sierra Madre-Cucamonga fault system [Spotila et al., 2002; Lavé and Burbank, 2004; DiBiase et al., 2010]. Due to their proximity to metropolitan Los Angeles and their association with earthquake, fire, flooding, and debris flow hazards, the SGM have been intensely studied for nearly a 
century [Eaton, 1935; Krammes, 1965; Wells, 1987; Heimsath et al., 2012]. The sites for this study are located primarily in the upper reaches of Little Santa Anita Canyon at elevations of 1200-1400 m, with mean local hillslope angles between $30^{\circ}$ and $45^{\circ}$ (Figure 1a). We focused on a region that had not been burned since 1954 (Fire and Resource Assessment Program, California Department of Forestry and Fire Protection, http://frap.cdf.ca.gov), and for comparison, we also investigated nearby sites that were burned in the 2009 Station Fire.

\section{Sediment Trapping by Vegetation}

[5] We begin with the hypothesis that sediment volume, $V$, behind vegetation dams on steep slopes can be described by a pyramidal geometry as

$$
V=\frac{1}{24} W^{3} \frac{\tan ^{2} \gamma}{\tan S-\tan \alpha},
$$

where $W$ is the effective dam width, $S$ is the local hillslope angle, $\gamma$ is the pile side slope, and $\alpha$ is the pile top slope [e.g., Fu, 2004] (Figure 2). To test the model, we characterized geometries and measured volumes of 22 sediment piles behind vegetation dams on local slopes (averaged over $5 \mathrm{~m}$ ) ranging from $30^{\circ}$ to $48^{\circ}$.

[6] We measured piles behind three vegetation types: trees (Pseudotsuga macrocarpa), shrubs (Ceonothus), and yuccas (Hesperoyucca whipplei), as well as for yuccas burned during the 2009 Station Fire (see Table S1 in the Supporting Information). We measured pile and plant dimensions and local slopes using a tape measure and clinometer, and determined sediment volume and mass by excavating sediment piles into 5 gal buckets and weighing material in the field. We defined the sediment pile behind each plant as the accumulation above the local thickness of mobile soil, if present. We defined the plant width as the width of live vegetative cover at the base of the plant. For select unburned yuccas, we also measured the diameter of the caudex (base) to develop a relationship between the caudex diameter and effective dam width. At the burned sites, surviving yuccas lacked basal vegetative cover except for the caudex, and we used measurements of the caudex diameter to infer the prefire effective dam width based on the relationship derived from unburned yuccas (Table S1).

[7] Field measurements show that the first-order control on sediment pile volumes for the three different vegetation types is the effective dam width (Figure 3a). Measured sediment volumes scale approximately with the effective dam width cubed and indicate that pile geometries grow similarly, consistent with equation (1). Measurements of sediment trapped behind recently burned yuccas suggest that following fire, yuccas release at least $75 \%$ of accumulated material by mass wasting due to the incineration of the dam and of organic material within the pile itself(Figure 3a). This is a minimum estimate as 100\% sediment release is observed for yuccas that are completely incinerated. For shrubs and yuccas, we found that the effective dam width is similar to (or less than) the plant width, which includes both the basal stems and low-lying vegetative material (Figure 3b). For trees, however, the effective dam width is larger than the basal trunk diameter due to trapped ground litter (Figure 3b). In contrast to shrubs and yuccas, trees often remain standing following fire, and it is likely that the burning of this trapped ground litter destabilizes accumulated sediment piles rather than
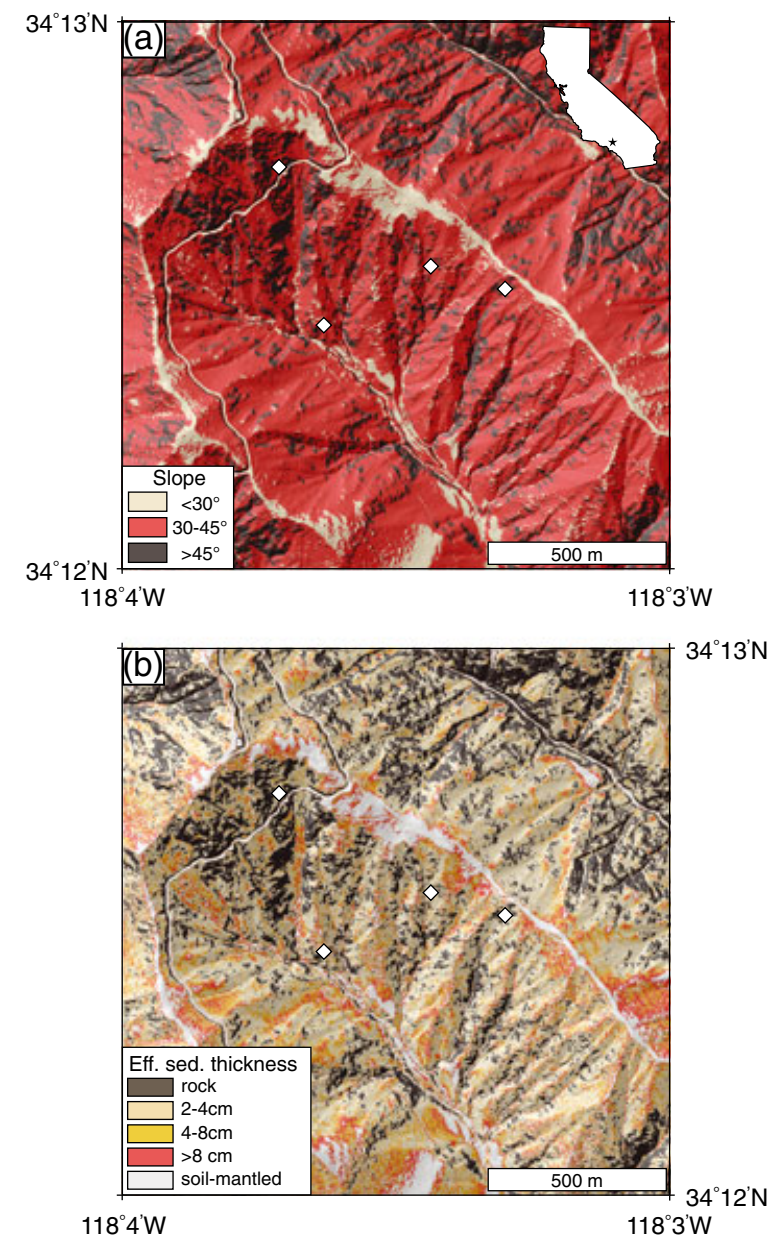

Figure 1. Map of the study area in the San Gabriel Mountains, California. (a) LiDAR slope map highlighting local (averaged over $5 \mathrm{~m}$ ) hillslope angles between $30^{\circ}$ and $45^{\circ}$ (red) where sediment accumulation behind vegetation dams is prevalent. Diamonds indicate unburned sample locations within this catchment (Table S1). (b) Predicted hillslope sediment thickness for the study area. Hillslopes less than $30^{\circ}$ are assumed to be soil-mantled, while hillslopes greater than $45^{\circ}$ are assumed to be bedrock. Note that equation (1) predicts that storage capacity becomes infinite as $\tan S$ approaches $\tan \alpha$ (corresponding to a continuous soil mantle) and becomes small as local slopes become increasingly steep.

the loss of live vegetative material. Assuming a constant angle of $30^{\circ}$ for pile top and side slopes ( $\alpha$ and $\gamma$, Figure $2 b$ ), which corresponds to the angle of repose for loose noncohesive sediment and is consistent with field observations, and using the measured local slope and vegetation dam width, the predicted vegetation storage capacities from equation (1) agree well with field-measured volumes (Figure 3c).

\section{Catchment-Scale Estimates of Transient Sediment Storage}

[8] The strong agreement between the field measurements and predictions from equation (1) (Figure 3c) enables the quantification of transient hillslope sediment storage at the catchment scale if the size and distribution of vegetation cover are known. We generated a map of hillslope sediment storage capacity over a $2.4 \mathrm{~km}^{2}$ region of the study area by 


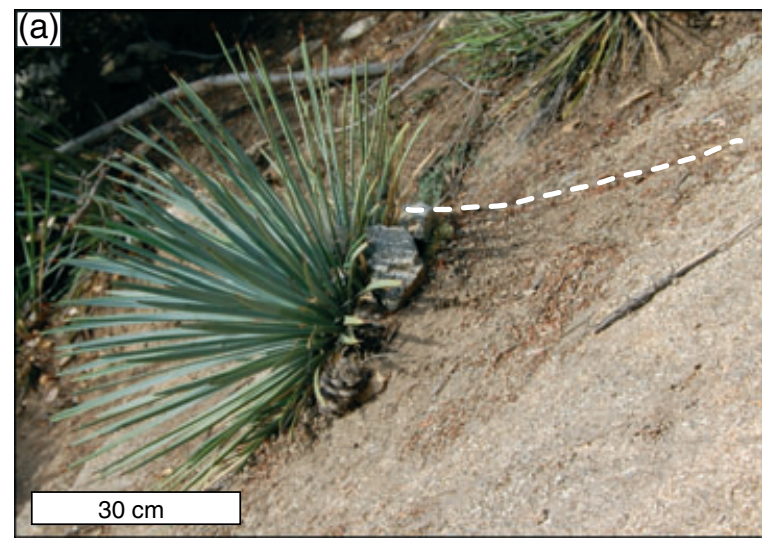

(b)

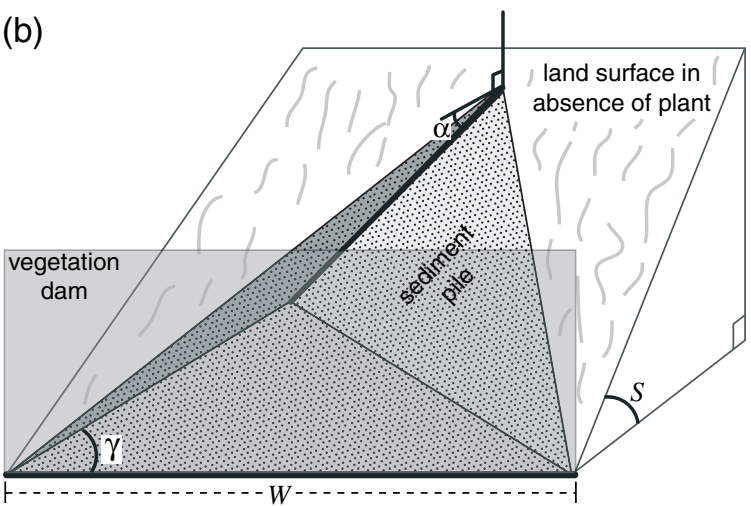

Figure 2. Geometric model for sediment piles. (a) Sediment accumulation behind yucca on an otherwise bare rock slope (sg12011104; Table S1). Dashed line indicates top profile of the sediment pile. (b) Schematic showing pyramidal geometry and dam width $(W)$, hillslope angle $(S)$, and sediment pile angles $(\alpha$ and $\gamma)$ used in equation (1).

applying equation (1) to a $1 \mathrm{~m}$ resolution LiDAR-derived digital elevation model (Figure 1b). At each grid cell, we calculated the effective sediment thickness averaged over the cell area $H$ as $H=c V$, where $c$ is the plant density per unit area and $V$ is the volumetric sediment storage capacity per plant. We used a stem density of 0.5 plants $/ \mathrm{m}^{2}$ from nearby vegetation surveys [Keeley, 1992] and for simplicity assumed an average effective dam width of $1 \mathrm{~m}$, based on field observations (Figure 3). We assumed $\alpha=\gamma=30^{\circ}$ and used LiDAR-derived measurements of the local hillslope angle averaged over five cells to determine $S$, which varies across the landscape. Field observations indicate that for local slope angles less than $30^{\circ}$, a continuous soil mantle exists, and sediment piles diffuse across the landscape. On slopes steeper than $45^{\circ}$, vegetation is sparse, as indicated from analyzing LiDAR first returns, and hillslopes are rocky [DiBiase et al., 2012] (Figure 4). As we are primarily interested in quantifying the volume of sediment that is unstable in the absence of vegetation dams, we applied equation (1) only to cells in the landscape with hillslope angles between $30^{\circ}$ and $45^{\circ}$. Our map of effective sediment pile thickness (Figure 1b) highlights these three distinct hillslope regimes based on local slope and emphasizes that it is the vegetation on slopes just steeper than the angle of repose that have the highest storage capacity for raveling sediment.

[9] Sediment pile bulk densities range from 0.4 to $1.8 \mathrm{~g} / \mathrm{cm}^{3}$ (Table S1), with a weighted mean of $1.1 \mathrm{~g} / \mathrm{cm}^{3}$ (combined mass of all samples divided by combined volume of all samples). Less dense piles reflect higher organic content, and assuming a bulk density of $1.8 \mathrm{~g} / \mathrm{cm}^{3}$ for the mineral fraction and $0.1 \mathrm{~g} / \mathrm{cm}^{3}$ for the organic fraction implies a mean organic content of $40 \%$. To convert sediment pile volumes and effective sediment thicknesses to equivalent bedrock lowering rates, we assumed an intact rock density of $2.6 \mathrm{~g} / \mathrm{cm}^{3}$ typical of granitic rock. Averaged over the entire study area, the storage capacity of sediment behind vegetation dams is equivalent to $\sim 3.5 \mathrm{~cm}$ of soil or $\sim 1.4 \mathrm{~cm}$ of rock after accounting for soil density and organic content.

\section{Implications for Landscape Evolution and Hazard Mitigation}

[10] The measured sediment storage by plants on steep slopes is large and likely dominates transient sediment fluxes in steep terrain. For example, nearby rates of soil production and catchment-averaged erosion rates measured from in situ
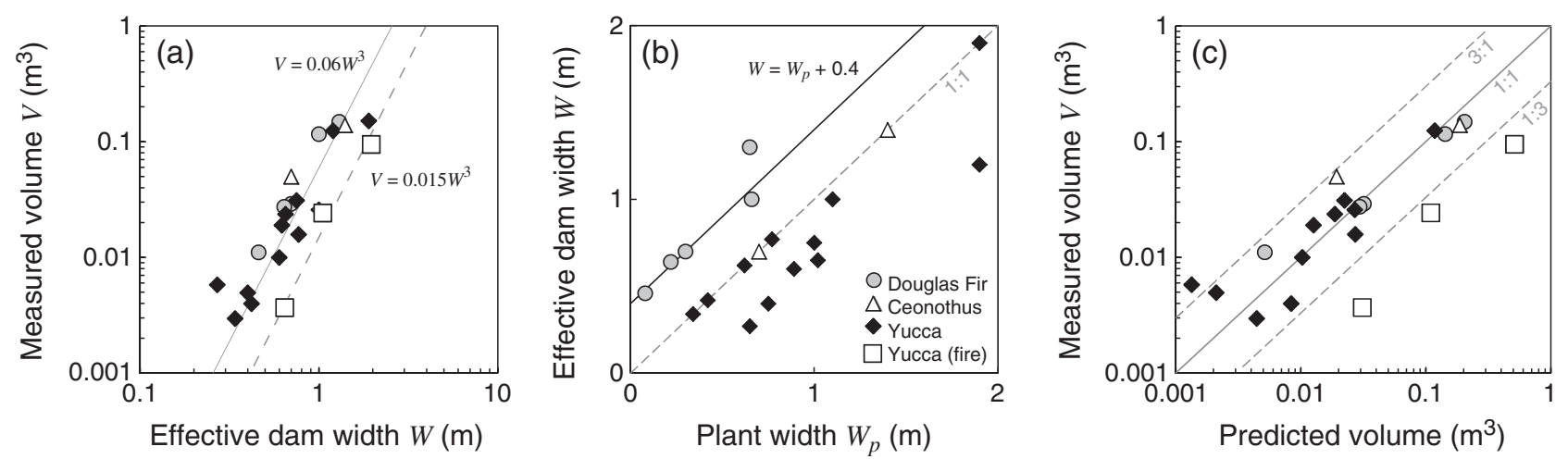

Figure 3. Field measurements of sediment accumulations behind vegetation dams. (a) Measured sediment pile volume ( $V$ ) versus effective vegetation dam width $(W)$ for all piles, with forced cubic regressions through unburned (solid line) and burned (dashed line) data points. Effective dam width may differ from measured plant dimensions (Figure 3b). For burned volumes, data are plotted using inferred prefire effective dam width. (b) Effective vegetation dam width ( $W$ ) versus plant width $\left(W_{p}\right)$. Solid line indicates linear fit to Douglas Fir data points, highlighting the role of downed branches extending vegetation dam influence. Dashed line is 1:1 for reference. (c) Measured sediment pile volume versus predicted volume from equation (1), assuming $\alpha=\gamma=30^{\circ}$. 


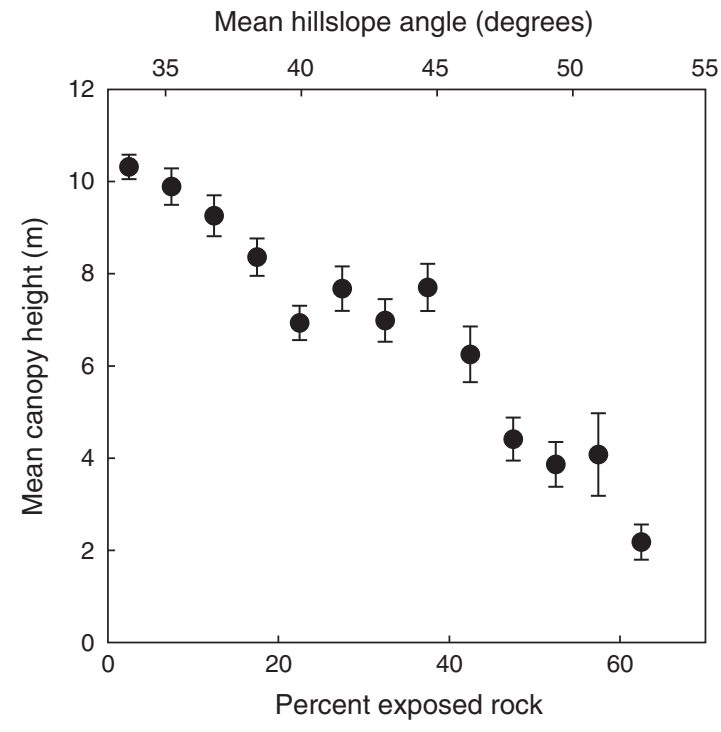

Figure 4. Vegetation canopy height as a function of slope and rock exposure. Mean canopy height determined from LiDAR first-return data decreases with increasing slope and rock exposure [DiBiase et al., 2012] for the region shown in Figure 1. Symbols show average for 1 ha blocks binned at intervals of $5 \%$ exposed rock, with error bars indicating the standard error on the mean for all blocks within each bin.

produced cosmogenic ${ }^{10} \mathrm{Be}$ concentrations in saprolite and stream sands are approximately $0.5 \mathrm{~mm} / \mathrm{yr}$ [DiBiase et al., 2010; Heimsath et al., 2012]. Thus, at a minimum, the material stored behind vegetation dams represents $\sim 30$ years of soil production (i.e., $14 \mathrm{~mm} / 0.5 \mathrm{~mm} \mathrm{yr}^{-1}=28$ years) and potentially much more if the trapping efficiency of vegetation dams is less than $100 \%$. Measurements of postfire pile volumes suggest a substantial loss following dam incineration (>75\%, Figure 3a), and for hillslopes steeper than the angle of repose for loose sediment, this material will be transported rapidly to the channel network. Our model provides a process-based explanation for the immediate loading of channels by dry ravel that is well documented in the SGM following wildfire [e.g., Rice, 1982]. Compilations of debris basin records indicate that in the first years following wildfire, catchment-scale sediment yields can increase tenfold [Lavé and Burbank, 2004; Lamb et al., 2011], often in the form of catastrophic debris flows [e.g., Eaton, 1935]. Our field measurements illustrate how these postfire sediment hazards can be assessed directly before wildfire.

[11] Current approaches to modeling landscape response to wildfire either treat hillslope processes with statistical regression models [Cannon et al., 2010b] or focus on soilmantled landscapes where continuum models of soil transport are appropriate [Roering and Gerber, 2005; Jackson and Roering, 2009]. A common prediction from such models is that an increase in sediment yield following fires is additive to the "background" sediment yield in the absence of fire so that increased fire frequency will result in increased sediment yield [Lavé and Burbank, 2004; Roering and Gerber, 2005], predictions that are ultimately relevant for landscapes with thick soil mantles without a supply limitation. These feedbacks occur because of the strong coupling between soil transport, thickness, and production in soil-mantled landscapes [Heimsath et al., 1997; Roering,
2008] and imply that the conversion of bedrock to soil depends on fire frequency; thus, fires leave a long-term signature on landscape form. The same feedbacks are not likely to hold in bedrock landscapes, where the observation of exposed bedrock and hillslopes with gradients that exceed the threshold for sediment stability (e.g., Figure 1a) indicates that the rates of sediment production and soil transport are decoupled and that the threshold for sediment stability is divorced from any threshold in the topographic slope [Burbank et al., 1996].

[12] Owing to the potential for significant transient storage and release of soil in bedrock landscapes, an increase in the rate of soil production is not needed to explain wildfireinduced sediment yield, with implications for the predicted increase in fire frequency due to climate change over the next century [e.g., Westerling and Bryant, 2008]. For the steep bedrock hillslopes described here, sediment response to fire is governed by the volume of trapped material behind vegetation dams, which depends on the soil production rate, the vegetation regrowth rate, and the time since the last fire [Lamb et al., 2011]. Because the timescale of refilling sediment behind vegetation dams is both longer than the time for plants to recover and similar to current fire recurrence intervals [Lamb et al., 2011], the rate of soil production is the rate-limiting step in determining the storage of underfilled vegetation dams. Therefore, a change in fire regime towards more frequent fires may not result in increased sedimentation rates due to supply limitations. Furthermore, our results suggest that on slopes that exceed the angle for sediment stability, sediment flux is controlled by biogeomorphic interactions that may be sensitive to climatic variations in a way not previously recognized.

[13] Acknowledgments. This work was supported by funding from the Davidow Foundation grant to M.P.L. Laser altimetry was acquired and processed by the National Center for Airborne Laser Mapping (NCALM) with support from the California Institute of Technology, Arizona State University, and the U.S. Geological Survey. Ben Mackey assisted with the fieldwork. Comments from two anonymous reviewers helped improve an earlier version of this manuscript.

\section{References}

Burbank, D. W., J. Leland, E. Fielding, R. S. Anderson, N. Brozovic, M. R. Reid, and C. Duncan (1996), Bedrock incision, rock uplift and threshold hillslopes in the northwestern Himalayas, Nature, 379(6565), 505-510, doi:10.1038/379505a0.

Cannon, S. H., J. E. Gartner, M. G. Rupert, J. A. Michael, D. M. Staley, and B. B. Worstell (2010a), Emergency assessment of postfire debris-flow hazards for the 2009 Station Fire, San Gabriel Mountains, southern California, U.S. Geological Survey Open-File Report 2009-1227, 1-27 pp.

Cannon, S. H., J. E. Gartner, M. G. Rupert, J. A. Michael, A. H. Rea, and C. Parrett (2010b), Predicting the probability and volume of postwildfire debris flows in the intermountain western United States, Geological Society of America Bulletin, 122(1-2), 127-144, doi:10.1130/b26459.1.

DiBiase, R. A., A. M. Heimsath, and K. X. Whipple (2012), Hillslope response to tectonic forcing in threshold landscapes, Earth Surface Processes and Landforms, 37(8), 855-865, doi:10.1002/esp.3205.

DiBiase, R. A., K. X. Whipple, A. M. Heimsath, and W. B. Ouimet (2010), Landscape form and millennial erosion rates in the San Gabriel Mountains, CA, Earth and Planetary Science Letters, 289(1-2), 134-144, doi:10.1016/j.epsl.2009.10.036.

Dietrich, W. E., D. Bellugi, A. M. Heimsath, J. J. Roering, L. Sklar, and J. D. Stock (2003), Geomorphic transport laws for predicting landscape form and dynamics, in Prediction in Geomorphology, edited by P. Wilcock and R. Iverson, pp. 103-132, American Geophysical Union, Washington, D.C.

Eaton, E. C. (1935), Flood and erosion control problems and their solution, Trans. Am. Soc. Civ. Eng., 101, 1302-1330.

Florsheim, J. L., E. A. Keller, and D. W. Best (1991), Fluvial sediment transport in response to moderate storm flows following chaparral 


\section{DIBIASE AND LAMB: SEDIMENT STORAGE BEHIND VEGETATION DAMS}

wildfire, Ventura County, southern California, Geological Society of America Bulletin, 103(4), 504-511, doi:10.1130/0016-7606(1991) $103<0504$ :fstirt $>2.3$. co; 2 .

Fu, X. (2004), A physical model of dry ravel movement, MS Thesis, 105 pp, Washington State University.

Gabet, E. J. (2003), Sediment transport by dry ravel, J. Geophys. Res., 108(B1), 2049, doi:10.1029/2001jb001686.

Gabet, E. J., and M. K. Mendoza (2012), Particle transport over rough hillslope surfaces by dry ravel: Experiments and simulations with implications for nonlocal sediment flux, J. Geophys. Res., 117, F01019, doi:10.1029/2011jf002229.

Heimsath, A. M., R. A. DiBiase, and K. X. Whipple (2012), Soil production limits and the transition to bedrock-dominated landscapes, Nat. Geosci. 5(3), 210-214, doi:10.1038/ngeo1380.

Heimsath, A. M., W. E. Dietrich, K. Nishiizumi, and R. C. Finkel (1997), The soil production function and landscape equilibrium, Nature, 388(6640), 358-361, doi:10.1038/41056.

Jackson, M., and J. J. Roering (2009), Post-fire geomorphic response in steep, forested landscapes: Oregon Coast Range, USA, Quaternary Science Reviews, 28(11-12), 1131-1146, doi:10.1016/j.quascirev.2008.05.003.

Kean, J. W., D. M. Staley, and S. H. Cannon (2011), In situ measurements of post-fire debris flows in southern California: Comparisons of the timing and magnitude of 24 debris-flow events with rainfall and soil moisture conditions, J. Geophys. Res., 116, F04019, doi:10.1029/2011jf002005.

Keeley, J. E. (1992), Demographic-structure of California chaparral in the long-term absence of fire, Journal of Vegetation Science, 3(1), 79-90, doi: $10.2307 / 3236001$.

Krammes, J. S. (1965), Seasonal debris movement from steep mountainside slopes in southern California, paper presented at Proceedings of the Second Federal Interagency Sedimentation Conference, U.S. Dept. of Agric., Washington, D.C.

Lamb, M. P., J. S. Scheingross, W. H. Amidon, E. Swanson, and A. Limaye (2011), A model for fire-induced sediment yield by dry ravel in steep landscapes, J. Geophys. Res., 116, F03006, doi:10.1029/2010jf001878.
Lavé, J., and D. Burbank (2004), Denudation processes and rates in the Transverse Ranges, southern California: Erosional response of a transitional landscape to external and anthropogenic forcing, Journal of Geophysical Research-Earth Surface, 109, F01006, doi:10.1029/ 2003jf000023.

Rice, R. M. (1982), Sedimentation in the Chaparral: How do you handle unusual events? Rep., 39-49 pp, U.S. For. Serv., Washington, D.C.

Roering, J. J. (2008), How well can hillslope evolution models "explain" topography? Simulating soil transport and production with high-resolution topographic data, Geological Society of America Bulletin, 120(9-10), 1248-1262, doi:10.1130/b26283.1.

Roering, J. J., and M. Gerber (2005), Fire and the evolution of steep, soilmantled landscapes, Geology, 33(5), 349-352, doi:10.1130/g21260.1.

Roering, J. J., J. W. Kirchner, L. S. Sklar, and W. E. Dietrich (2001), Hillslope evolution by nonlinear creep and landsliding: An experimental study, Geology, 29(2), 143-146, doi:10.1130/0091-7613(2001) $029<0143$ :hebnca $>2.0$. co;2.

Selby, M. J. (1993), Hillslope Materials and Processes, 2nd ed., 451 pp., Oxford University Press, Oxford

Spotila, J. A., M. A. House, A. E. Blythe, N. A. Niemi, and G. C. Bank (2002), Controls on the erosion and geomorphic evolution of the San Bernardino and San Gabriel Mountains, southern California, Geological Society of America Special Paper, 365, 205-230.

Tucker, G. E., and G. R. Hancock (2010), Modelling landscape evolution, Earth Surface Processes and Landforms, 35(1), 28-50, doi:10.1002/ esp.1952.

Tucker, G. E., and D. N. Bradley (2010), Trouble with diffusion: Reassessing hillslope erosion laws with a particle-based model, J. Geophys. Res., 115, F00A10, doi:10.1029/2009jf001264.

Wells, W. G. (1987), The effect of fire on the generation of debris flows in southern California, Rev. Eng. Geol., 7, 105-114.

Westerling, A., and B. Bryant (2008), Climate change and wildfire in California, Clim. Chang., 87(0), 231-249, doi:10.1007/s10584-0079363-z. 